\title{
Production of Recombinant Enzymatic Mixture by Co-culture Strategy
}

\author{
M. R. SILVA ${ }^{1}$, D. S. GOMES ${ }^{1}$ and S. FREITAS ${ }^{1}$ \\ 1 Brazilian Center for Research in Energy and Materials (CNPEM), Brazilian Bioethanol Science and \\ Technology Laboratory (CTBE) \\ E-mail address: mateus.silva@bioetanol.org.br (M. R. SILVA)
}

\begin{abstract}
Sugarcane bagasse is considered to be a residue with great potential as feedstock for second-generation ethanol production, and other added-value products. However, certain obstacles must be overcome to make this technology viable, as in the case of enzymatic route in which the high cost of enzymes production, and the low efficiency in the saccharification step still represent a bottleneck. Recently, recombinant enzymes have been used as supplement fungal cocktails to improve lignocellulosic biomass saccharification, as well as to assembly specific enzymatic mixtures aiming at other applications. In this study, we present the development of recombinant enzymatic mixture production process based on co-culture strategy. The process development includes the inoculum assembly, screening of alternative carbon sources, and improve of induction phase. Escherichia coli clones co-culture present as main advantages: the possibility to produce an enzymatic mixture with a desired composition based on inoculum assembling, the use of low cost carbon source as hemicellulosic hydrolysates based on complete metabolic machinery of $E$. coli, and reduction of the production process and recovery costs since more than one enzyme is produced in the same reactor.
\end{abstract}

\section{INTRODUCTION}

Sugarcane bagasse is a lignocellulosic residue with great potential as feedstock for secondgeneration ethanol production or other value-added products. One of the approaches studied for making use of this material is the utilization of enzymes to hydrolyze the cell wall carbohydrates and generate fermentable sugars. These enzymes can be produced mainly by the cultivation of filamentous fungi, however, recent studies indicate that the new generation of enzyme cocktails tends to be formulated by adding other enzymes in concentrations appropriate for the given pretreated material (Gao et al., 2011). Several studies have reported the beneficial effect of adding recombinant enzymes in different phases during the hydrolysis reaction (Gao et al., 2011; Zhou et al., 2009).

Escherichia coli is the most used platform for recombinant protein expression since it is a well characterized microorganism (Lee, 1996), grows well under aerobic and anaerobic conditions, shows efficient performance in industrial scale and ability to use several substrates as carbon source, which confer it a very important capability as a cell factory (Shimizu, 2013). Besides, it is easily manipulated by metabolic engineering and synthetic biology, and can be engineered to produce a wide variety of products. Co-culture has been proved to be a simple way to obtain mixtures of 


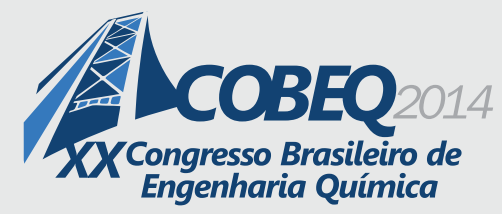

19 a 22 de outubro de 2014

Florianópolis/SC

proteins that work together in a specific bioconversion reaction (Shin et al., 2010). In this strategy, two or more clones, each transformed with a plasmid containing the gene coding for each desired protein, are cultivated in the same culture vessel and induced at the same time (Nehme et al., 2010; Shin et al., 2010).

In the present study we evaluate the production of a recombinant mixture of hydrolases based on co-culture strategy.

\section{MATERIALS AND METHODS}

\subsection{Bacterial strain and culture media}

The microorganism used in this study was E. coli BL21 (DE3) (Merck, USA), harboring the pET28-a-c(+) vector (Novagen) carrying either $\beta-1,3-1,4-$ endoglucanase, expansin (GH61 family)

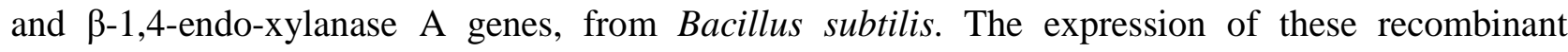
proteins was under the control of the $\mathrm{T} 7$ promoter.

The defined medium (per liter) in the batch phase of bioreactor cultivations was composed of carbon source (10 to $50 \mathrm{~g}), \mathrm{KH}_{2} \mathrm{PO}_{4}(13.3 \mathrm{~g}),\left(\mathrm{NH}_{4}\right)_{2} \mathrm{HPO}_{4}(4.0 \mathrm{~g}), \mathrm{MgSO}_{4} \cdot 7 \mathrm{H}_{2} \mathrm{O}(1.2 \mathrm{~g})$, citric acid $(1.7 \mathrm{~g})$, EDTA $(14.1 \mathrm{mg})$, trace element solution $(1 \mathrm{~mL}), \mathrm{Fe}(\mathrm{III})$ citrate $(100.8 \mathrm{mg})$, thiamine $\mathrm{HCl}(4.5$ $\mathrm{mg}$ ) and kanamycin sulfate $(30 \mathrm{mg})$. The feed medium consisted of carbon source $(500 \mathrm{~g}), \mathrm{KH}_{2} \mathrm{PO}_{4}$ $(13.3 \mathrm{~g}),\left(\mathrm{NH}_{4}\right)_{2} \mathrm{HPO}_{4}(4.0 \mathrm{~g}), \mathrm{MgSO}_{4} \cdot 7 \mathrm{H}_{2} \mathrm{O}(20 \mathrm{~g})$, citric acid $(1.7 \mathrm{~g})$, EDTA $(28.2 \mathrm{mg})$, trace element solution $(2 \mathrm{~mL}), \mathrm{Fe}(\mathrm{III})$ citrate $(201.6 \mathrm{mg})$, thiamine $\mathrm{HCl}(4.5 \mathrm{mg})$ and kanamycin sulfate (30 $\mathrm{mg}$ ). The trace element solution contained (per liter): $\mathrm{CoCl}_{2} \cdot 6 \mathrm{H}_{2} \mathrm{O}(2.5 \mathrm{~g}), \mathrm{MnCl}_{2} \cdot 4 \mathrm{H}_{2} \mathrm{O}(15.0 \mathrm{~g})$, $\mathrm{CuCl}_{2} \cdot 2 \mathrm{H} 2 \mathrm{O}(1.5 \mathrm{~g}), \mathrm{H}_{3} \mathrm{BO}_{3}(3.0 \mathrm{~g}), \mathrm{Na}_{2} \mathrm{MoO}_{4} \cdot 2 \mathrm{H}_{2} \mathrm{O}(2.1 \mathrm{~g})$ and $\mathrm{Zn}\left(\mathrm{CH}_{3} \mathrm{COO}\right)_{2} \cdot 2 \mathrm{H}_{2} \mathrm{O}(33.8 \mathrm{~g})$.

\subsection{Experiments}

The inoculum was prepared by transferring $100 \mu 1$ of cell suspension kept in liquid nitrogen to a $500 \mathrm{~mL}$ Erlenmeyer flask containing $100 \mathrm{~mL}$ of sterile culture medium (defined medium or LB) and incubating it at $37^{\circ} \mathrm{C}$ and $250 \mathrm{rpm}$ for $16 \mathrm{~h}$. A known volume of the resulting bacterial suspension was transferred to the bioreactor in order to obtain an initial $\mathrm{OD}_{600 \mathrm{~nm}}$ of 0.2 .

The experiments were carried out in a Bioflo 115 bioreactor (Eppendorf, USA) with a nominal capacity of $3 \mathrm{~L}$. Temperature was maintained at $37^{\circ} \mathrm{C}$ and the $\mathrm{pH}$ controlled at 7.0 by addition of $25 \%$ $\mathrm{NH}_{4} \mathrm{OH}(\mathrm{v} / \mathrm{v})$ solution. Polypropylene glycol (PPG) was used as the antifoam agent when necessary. Protein expression was induced by addition of $1 \mathrm{mM}$ of isopropyl- $\beta$-D-thiogalactopyranoside (IPTG, Sigma-Aldrich). Dissolved oxygen tension was kept at $30 \%$ air saturation by supplying specific air at 1.0 VVM to the batch cultivation and 1.0-2.0 VVM to the fed-batch cultivation. In the latter, pure oxygen was used as needed. Samples were collected at regular intervals to cell growth measurement and determination of organic acid production, carbon source consumption, protein concentration, enzyme activity, plasmid stability, and in the co-culture experiments, evaluation of the competition. The initial volume of culture medium was 1.0 and $0.85 \mathrm{~L}$ to batch and fed-batch cultivation, respectively. 


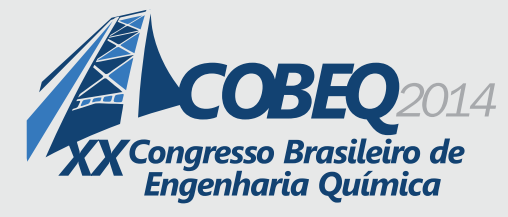

19 a 22 de outubro de 2014

Florianópolis/SC

In fed-batch cultivation, the specific growth rate $(\mu)$ was kept constant at $0.1 \mathrm{~h}^{-1}$. Feeding was started when the carbon source added to the batch phase was completely exhausted. The exponential feed flow rate was automatically implemented and Eq. (1), proposed by Lee (Lee, 1996), was used to define the feed profile.

$$
M_{S}=\left(\frac{\mu}{Y_{X /}}+m\right) \cdot C_{x}\left(t_{0}\right) \cdot V\left(t_{0}\right) \cdot \exp ^{\left[\mu\left(t-t_{0}\right)\right]}
$$

$\mathrm{M}_{\mathrm{S}}=$ mass flow of substrate $(\mathrm{g} / \mathrm{h}) ; \mu=$ desired specific growth rate $\left(\mathrm{h}^{-1}\right) ; \mathrm{m}=$ specific maintenance coefficient $(0.025 \mathrm{~g}$ $\left.\mathrm{g}(\mathrm{DCW})^{-1} \cdot \mathrm{h}^{-1}\right) ; \mathrm{V}=$ culture volume $(\mathrm{L}) ; \mathrm{Y}_{\mathrm{X} / \mathrm{S}}=$ yield coefficient for biomass formation $(0.5 \mathrm{~g} \mathrm{DCW} / \mathrm{g} \mathrm{S}) ; \mathrm{CX}=\mathrm{biomass}$ concentration $\left(\mathrm{g}\right.$ DCW/L); $\mathrm{t}_{0}=$ values of volume, biomass and glucose concentrations at the onset of the feeding.

\subsection{Analytical methodology}

The cell growth was measured by optical density at $600 \mathrm{~nm}$ (OD) and dry cell weight (DCW). Cell pellets were resuspended with $1 \mathrm{~mL}$ of buffer $-25 \mathrm{mM}$ Tris $\mathrm{HCl} \mathrm{pH} 7.5,150 \mathrm{mM} \mathrm{NaCl}, 0.3$ $\mathrm{mg} / \mathrm{mL}$ lysozyme, and $1 \mathrm{mM}$ phenylmethane-sulfonylfluoride (PMSF-protease inhibitor) and broken down by sonication (Sonics - Vibra Cell). The soluble cell extracts were used to determine enzymatic activity and total protein concentration.

Total protein concentration was determined by the Bradford method (Bradford, 1976) following the manufacturer's instructions. Bovine serum albumin was used as a protein standard to construct the calibration curve $(5-250 \mathrm{~g} / \mathrm{mL}$ range). The enzymatic activities were determined following the protocol of Ghose and Bisaria [26,27] using 0.5\% $\beta$-glucan (w/v) and 0.5\% Birchwood xylan (w/v) as specific substrates for endoglucanase and xylanase activities. After the reaction, the reducing sugars were determined by DNS (1,4-dinitrosalisilic acid) assay (Miller, 1959). One unit of enzymatic activity was defined as the amount of enzyme that releases 1 mmol of product (xylose or glucose) per minute. Specific activities were expressed as units per mg of protein.

Protein expression was qualitatively analyzed by sodium dodecyl sulfate-polyacrylamide gel electrophoresis (SDS-PAGE) with 12\% (w/v) acrylamide (Laemmli, 1970). Firstly, samples were prepared by adjusting cell suspensions to reach an $\mathrm{OD}_{600 \mathrm{~nm}}$ value of 5.0. Cell lysis was reached by adding a buffer containing SDS and betamercaptoethanol followed by heating at $99 \circ \mathrm{C}$ for $15 \mathrm{~min}$. Then $20 \mu \mathrm{L}$ of the samples were applied to each lane of the gel. After the run, the gels were stained with Coomassie Brilliant Blue R250. Quantitative analysis of SDS-PAGE was performed by LabImage software based on the protocol developed by our group (Gomes, 2013). In this case, 5,000 ng of total protein was applied to each lane of the electrophoresis gel, and after the run, stained with Coomassie Blue. An image created by scanner (Image Scanner III, GE) combined with the LabScan software was analysed by LabImage 1D to relate the band volume with protein concentration. BSA was used as protein standard to construct the calibration curve (20 to $200 \mathrm{ng} / \mu \mathrm{L}$ range).

Plasmid stability was determined by serial dilution in a $150 \mathrm{mM} \mathrm{NaCl}$ cell suspension. An aliquot of $100 \mu \mathrm{L}$ was plated in LB agar and incubated at $37 \circ \mathrm{C}$ for $24 \mathrm{~h}$. After incubation, around 50 colonies were replicated on LB agar plates with and without kanamycin sulfate $(30 \mathrm{mg} / \mathrm{L})$ and 


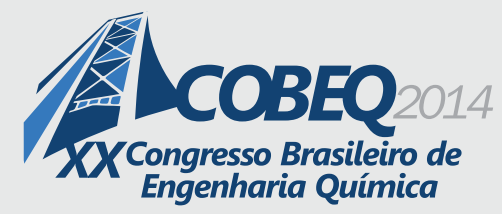

incubated at $37{ }^{\circ} \mathrm{C}$ for $24 \mathrm{~h}$. Stability was determined as the percentage of kanamycin-resistant colonies.

Determination of carbohydrate and organic acid concentrations was performed by HPLC coupled with RID detection. Cell-free samples of the culture were diluted ten times with $0.005 \mathrm{M}$ sulfuric acid, treated with Sep-Pack C18 and injected into the HPX-87H $300 \mathrm{~mm} \times 7.8 \mathrm{~mm}$ column (Bio Rad). The mobile phase used was $0.005 \mathrm{M}$ sulfuric acid with a flow rate of $0.5 \mathrm{~mL} / \mathrm{min}$ at $50{ }^{\circ} \mathrm{C}$.

\section{RESULTS AND DISCUSSION}

\subsection{Hydrolases mixture composition by inoculum assembling}

Recently, co-culture assays were performed in our laboratory at CTBE in order to evaluate the potentiality to compose the recombinant enzymatic mixture by inoculum assembling (Gomes, 2013). This set of experiments was validated in bioreactor using the proportion of $33 \%$ for each enzyme. The expression of the recombinant protein mixture was confirmed by SDS-PAGE. Further, analysis of the SDS-PAGE by band densitometry showed that the experimental proteins ratio were quite similar to that expected by inoculum proportion (Figure 1), suggesting that we can compose the percentage of recombinant proteins in the co-culture through the inoculum assembling .

A

\begin{tabular}{|lccc|}
\hline \multicolumn{1}{|c}{ Enzyme } & $\begin{array}{c}\text { MW } \\
(\mathbf{k D a})\end{array}$ & $\begin{array}{c}\text { PP } \\
\mathbf{( \% )}\end{array}$ & $\begin{array}{c}\text { SD } \\
\mathbf{( \% )}\end{array}$ \\
\hline Endoglucanase & 53 & 34.8 & 1.03 \\
Expansin & 23 & 35.4 & 1.47 \\
Xylanase & 21 & 34.6 & 0.91 \\
\hline
\end{tabular}

MW - Molecular Weight; PP - Protein Proportion; SD - Standard Deviation

\section{B}

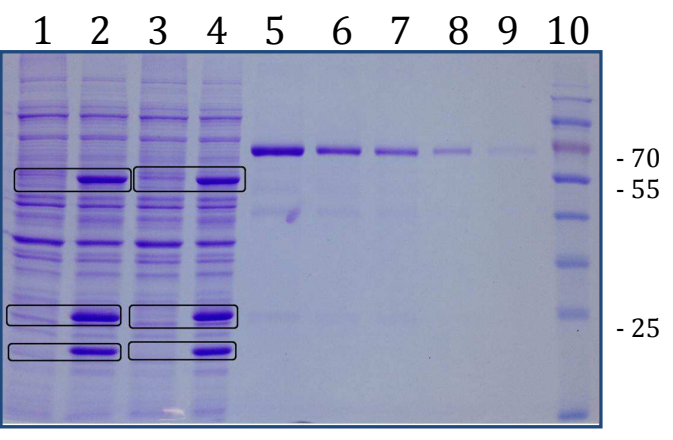

Figure 1. Analysis qualitative (SDS-PAGE) and quantitative (densitometry) of the recombinant proteins expression. A) Experimental proteins proportion obtained by co-culture; B) Expression of the recombinant enzymatic mixture. Lane 1 and 3- before induction; lane 2 and 4- three hours after induction; 5 to 9BSA calibration curve: respectively 200, 100, 80, 40 and $20 \mathrm{ng} / \mu \mathrm{L}$; Lane 10- protein ladder.

In fed-batch co-culture for xylanase and endoglucanase production, a proportion of $50 \%$ in the assembling of the inoculum was used. In 30 hours elapsed time, the plasmid stability remaining around $100 \%$, and the activity panel indicate that neither strain predominated over the other, since the proportion of clones remained almost the same as at the beginning of cultivation. The clone distribution was $50 \% \pm 5.6$ for the gene coding for xylanase activity and $45 \% \pm 3.2$ for that coding for endoglucanase activity (Figure 2). 


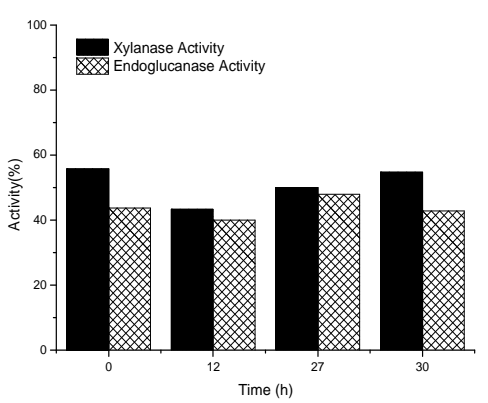

Figure 2. Determination of the endoglucanase and xylanase expression colonies - Percentages of each acitivity detected in different times of the co-cultivation process.

\subsection{Carbon sources screening}

The screening of carbon sources was performed to evaluate and compare the behavior of E.coli BL21 when cultivated in four carbohydrates (glucose, sorbitol, glycerol and xylose) and identify the potential of each carbohydrate regarding the process performance and metabolism efficiency in an industrial scale process. Experiments were performed in bioreactors with initial carbon concentration from 10 to $50 \mathrm{~g} / \mathrm{L}$ in order to identify the concentration point to obtain higher biomass yield. Process performance was strongly affected by the initial carbon concentration following the same pattern. By increasing the substrate level in the broth, there was a downward trend in the maximum specific cell growth rate (Figure 3A), as well as growth inhibition with a decline in the biomass yield (Figure 3B).
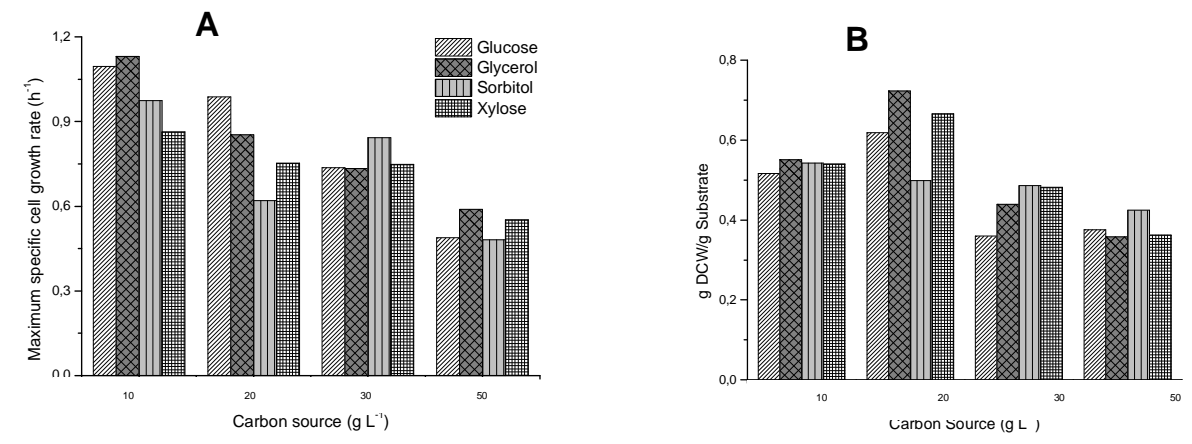

Figure 3. Kinetic profiles in different carbon sources concentration. A) Maximum specific cell growth rate and B) global biomass yield obtained during cultivation with different levels of substrate in the broth.

The highest cell growth rate was obtained with $10 \mathrm{~g} / \mathrm{L}$ of carbon source, while the highest biomass yield was achieved with $20 \mathrm{~g} / \mathrm{L}$. E. coli culture growth on high glucose concentration resulted in acetate accumulation, however, a series of bioprocess and molecular approaches to achieve high 


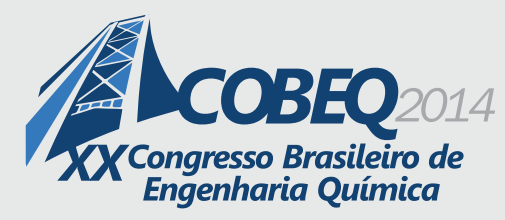

19 a 22 de outubro de 2014

Florianópolis/SC

cell density on this substrate have been described in the literature. Glycerol like glucose, showed the highest specific cell growth rate, biomass yield and productivity in batch culture with low carbon source concentration. Using xylose as carbon source, the productivity was severely impacted due to the long lag phase, although high cell growth rates and biomass yield were reached.

\subsection{Recombinant protein induction}

Studies on the induction phase were carried out to define the best moment to induce expression when working in co-culture. This was done at two different stages of growth, in the early and the mid-exponential phases. Samples were taken until 5 hours after induction. Results on the effect of induction time indicate that 3 hours of induction using IPTG were enough to reach the highest values of specific activity for clones. For this reason, an induction time of 3 hours was determined for further studies in batch and fed-batch mode. Induction at different stages of exponential growth showed that specific activity with induction in the early exponential phase was slightly higher than that of cultivations with induction in the mid-exponential phase (47.1 and 31.3 $\mathrm{U} / \mathrm{mg}$ protein for xylanase and 5.1 and $4.5 \mathrm{U} / \mathrm{mg}$ protein for endoglucanase, respectively). These results are similar to those obtained by Olaef and co-workers (Olaef et al., 2010) for production of a thermostable amidase. In terms of induction phase improvement, the replacement of IPTG by Lactose and the supplementation of the induction media with yeast extract were also evaluated aiming at getting a better expression performance (Figure 4). Lactose concentration affected positively the recombinant enzyme expression resulting in an increment of $31 \%$ (Figure 4B) at $1.6 \mathrm{mM}$ of Lactose/gDCW, the best result obtained in the range studied. Yeast extract improved biomass yield reaching an increment of 55\% at $15 \mathrm{gYE} / \mathrm{L}$ (Figure $4 \mathrm{C}$ ). The recombinant protein achieved an increment of $53 \%$ with $10 \mathrm{~g} / \mathrm{L}$ of yeast extract (Figure 4D).

Figure 4. Recombinant protein induction.

A) Cell growth profile; B) Percentage of recombinant protein obtained related to total protein at different lactose concentrations during induction phase; C) biomass yield obtained with YE supplementation in the induction phase; D) percentage of recombinant protein obtained related to total protein at different YE concentration in the induction phase.

YE - yeast extract

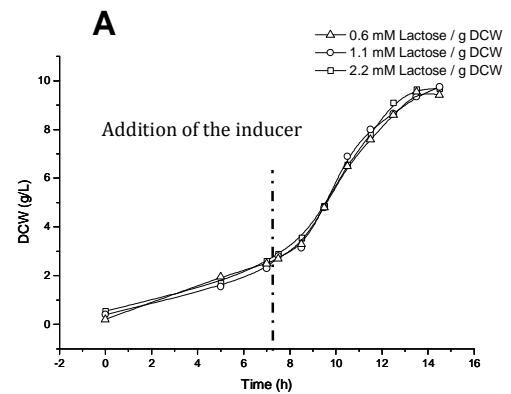

C

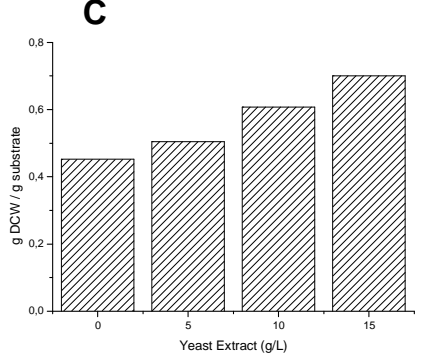

B

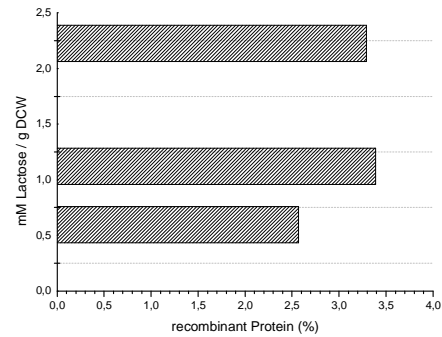

D

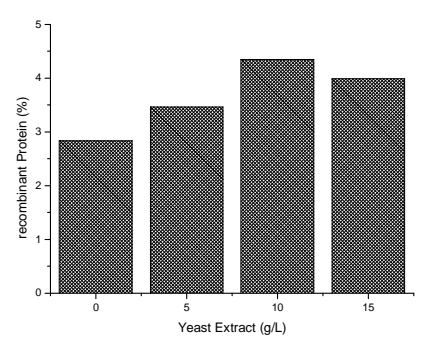




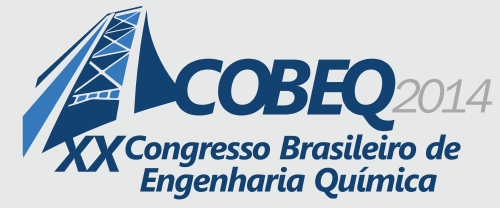

\section{CONCLUSIONS}

Escherichia coli displays metabolic tools that confer the capacity and versatility to utilize a variety of carbon sources. However, the increase of the carbon source concentration reduces the maximum specific cell growth rate and biomass yield. Glucose and xylose are the main composition of lignocellulosic material, a feedstock widely found in the environment, as well as glycerol, a biodiesel byproduct. For the industrial process, the availability and the knowledge accumulated on $E$. coli culture growth on glucose and glycerol make these carbon sources more mature options to be utilized in a near-term process development. The modulation of the recombinant enzymatic mixture can be easily assembled through the combination of the specific cell suspension proportions to compose the inoculum. Competition assay results showed that there was no predominance of any clone over the other, and clone distribution was mantained over 30 hours of cultivation. However, it is clear that the success of co-culture application requires well characterized clones, and the cultivation strategy has to take into account a commitment among similar kinetic parameters of growth, protein production and the characteristics of each protein being synthesized. Studies at the induction phase show that recombinant protein expression can be improved by adding yeast extract in the induction media and the production cost could be reduced replacing IPTG by lactose. An improved ratio of lactose concentration and cell density was found with an increment of $53 \%$ of the recombinant enzyme related to the total protein being expressed by E. coli. The co-culture approach appears as a potential strategy to produce a mixture of recombinant enzymes customized to each final application.

\section{REFERENCES}

BRADFORD, M.M. A rapid and sensitive method for the quantitation of microgram quantities of protein utilizing the principle of protein-dye binding. Analytical Biochemistry, 72 (1-2) (1976) 24854.

GAO, D.; UPPUGUNDLA, N.; CHUNDAWAT, P.S.; YU, X.; HERMANSON, S.; GOWDA, K.; BRUMM, P.; MEAD, D.; BALAN, V.; DALE, D.B. Hemicellulases and auxiliary enzymes for improved conversion of lignocellulosic biomass to monosaccharides. Biotechnology for Biofuels, (2011) 4:5

GOMES, D.S. Produção de misturas enzimáticas recombinantes utilizando a técnica de co-cultivo. Relatório de estágio realizado no Laboratório Nacional de Ciência e Tecnologia do Bioetanol CTBE/ CNPEM, (2013)

LEE, S.Y. High cell density culture of Escherichia coli. Tibtech, 14 (1996) 98-105. 
SHIMIZU, K. Metabolic Regulation of a Bacterial Cell System with Emphasis on Escherichia coli Metabolism. Biochemistry, (2013) 47.

LAEMMLI, U.K. Cleavage of structural proteins during the assembly of the head of bacteriophage T4. Nature, 2273 (1970) 397-407.

MILLER, G.L. Use of dinitrosalicylic acid reagent for determination of reducing sugar. Anal. Chem, 31 (1959) 426-428.

NEHME, N.; MATHIEU, F.; TAILLANDIER, P. Impact of the co-culture of Saccharomyces cerevisiae-Oenococcus oeni on malolactic fermentation and partial characterization of a yeast-derived inhibitory peptidic fraction. Food Microbiology, 27 (2010) 150-157.

OLAEF, O.A.; BURTON, S.G.; COWAN, D.A.; HARRISON, S.T.L. Improving of a thermostable amidase through optimising IPTG induction in a highly dense culture of recombinant Escherichia coli. Biochemical Engeneering journal. 52 (2010) 19-24.

SHIN, H.D.; MCCLEDON, S.; VO, T.; CHEN, R.R. Escherichia coli binary culture engineered for direct fermentation of hemicellulose to a biofuel. Applied and environmental microbiology, 76 (24) (2010) 8150-8159

ZHOU, J.; WANG, Y.H.; CHU, J.; LUO, L.Z.; ZHUANG, Y.P.; ZHANG, S.L. Optimization of cellulase mixture for efficient hydrolysis of steam-exploded corn stover by statistically designed experiments. Bioresour Technol, 100 (2009) 819-825. PubMed doi:10.1016/j.biortech.2008.06.068 